\title{
PHOSPHOCREATINE IMPROVES MUSCLE MICROCIRCULATION DURING EXERCISE
}

\author{
A FOSFOCREATININA MELHORA A MICROCIRCULAÇÃO MUSCULAR DURANTE O EXERCICIO \\ LAFOSFOCREATINA MEJORA LA MICROCIRCULACIÓN MUSCULARDURANTEEL EJERCICIO
}

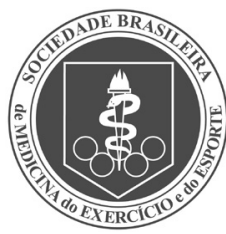

Original Article

ARTIGO ORIGINAL

Artículo Original
Lei $\mathrm{Ma}^{1}$ (1D)

(Physical Education Professional)

1. Physical Education Institute of Xi'an, Peihua University, Shaanxi, China,

\section{Correspondence}

Lei $\mathrm{Ma}$

Shaanxi,China, 710000

ma20201206@126.com

\begin{abstract}
Introduction: Phosphate (CP) its biosynthesis begins with the kidney. Glycocianine was synthesized from glycocianine, then methylated in the liver, and finally formed in each tissue. Objective: To study the effects of phosphatic acid in exercise training. Methods: This paper uses 50 pure male mice, 2 month old, weight at $22 \pm$ $3 \mathrm{~g}$, and mice per day, 5 minutes each time. After exercise training, dry dry with a towel and blow it with a hair dryer, and move it to the end of each other. Results: The average time of motion B mouse to give phosphate creatine is significantly longer than the average time of the non-administration of the A group, and the motion time is prolonged to extend $23.20 \%$. Phosphate has improved motor endurance and promotes improvement in muscle microcirculation during exercise. Conclusions: Motion can be used to improve the maximum aerobic capacity of exercise in motion. Level of evidence ll; Therapeutic studies - investigation of treatment results.
\end{abstract}

Keywords: Phosphocreatine; Exercise; Abdominal muscles.

\section{RESUMO}

Introdução: A biossíntese Its do fosfato começa no rim. Glicociamina foi sintetizado de glicocianina, e depois transformado em metilato no fígado; finalmente, desenvolve em cada tecido. Objetivo: Estudar os efeitos do ácido fosfato em treinamento de exercícios. Métodos: Este estudo usa 50 camundongos machos puros de dois meses de idade, pesando $\pm 3 g$ aos 22 meses, eXXX camundongos por dia por cinco minutos cada vez. Após o treino, estes foram secos com uma toalha e secador de cabelo e colocados um do lado do outro. Resultados: O tempo médio de movimento para o grupo $B$ de camundongos produzir fosfato de creatinina é consideravelmente mais longo do que o tempo médio do grupo A, onde não houve administração. O tempo de movimento se prolonga em 23,20\%. O fosfato melhora a resistência motora e promove uma melhora na microcirculação durante o exercício. Conclusões: O movimento pode ser usado para melhorar a capacidade aeróbica máxima do exercício em movimento. Nível de evidência ll; Estudos terapêuticos - investigação de resultados de tratamento.

Descritores: Fosfocreatina; Exercício; Músculos abdominais.

\section{RESUMEN}

Introducción: El biosíntesis del fosfato empieza en el riñón. La Glicociamina se sintetizó de Glicocianina, y después se transformó en metilato en el hígado; y finalmente, formó cada tejido. Objetivo: Estudiar los efectos del ácido fosfato en entrenamiento de ejercicios. Métodos: Este estudio utiliza 50 ratones machos puros de 2 meses de edad, pesando $\pm 3 \mathrm{~g}$ a los 22 meses, y xxx ratones por día por 5 minutos cada vez. Tras el entrenamiento, se los secó con una toalla y secador de pelo y se los puso lado a lado. Resultados: El tiempo medio de movimiento para el grupo $B$ de ratones producir fosfato de creatina es considerablemente más largo que el tiempo medio del grupo A, donde no hubo administración. El tiempo de movimiento se alarga en 23,20\%. El fosfato mejora la resistencia motora y promueve una mejoría en la microcirculación durante el ejercicio. Conclusiones: El movimiento puede usarse para mejorar la capacidad aeróbica máxima del ejercicio en movimiento. Nivel de evidencia ll; Estudios terapéuticos investigación de resultados de tratamiento.

Descriptores: Fosfocreatina; Ejercicio; Músculos abdominales.

\section{INTRODUCTION}

Phosphocreatine (CP) biosynthesis begins in the kidney. Glycocianine is formed by the synthesis of Glycocianine from glycine and arginine, which is then methylated to creatine in the liver, and finally phosphorylated in various tissues. ${ }^{1}$ Creatine phosphate has been widely used in the medical field, some inside the heart, surgical clinical application of creatine phosphate as a myocardial protective agent, used in the heart of the heart disease protection and myocardial metabolic distress when other symptoms, is suitable for the treatment of myocardial ischemia, hypertrophy, myocardial infarction and heart failure (adjuvant therapy), can also be used for a variety of cardiac surgery. ${ }^{2}$ Because phosphocreatine is not classified as a stimulant, it has been widely used in sports in recent years. Phosphoscreatine is a kind of high-energy phosphate in the body, most of which exists in the muscle tissue. It is not only an important energy for short and intense exercise, but also an emergency energy for the human body to start, accelerate and adapt to the rapid changes in 
environmental conditions. As we all know, ATP and CP together constitute the high-energy phosphide energy supply system in the human body, which is mainly used for short time and high intensity sports. However, football is a sport of running in a long time of intense struggle. ${ }^{3}$ Experiments have proved that aerobic endurance accounts for about 70\% $80 \%$ in football matches. The total distance of a football player on the field is about $1100 \mathrm{~m}$, so the improvement and development of maximum aerobic capacity has become a necessary condition for excellent football players. For athletes, the improvement of aerobic endurance will greatly improve their overall skill and tactical level. Therefore, whether phosphocreatine can also promote the long-term aerobic endurance of football players has become a very concerned issue. ${ }^{4}$

\section{METHOD}

\section{Subjects}

Healthy male Kunming mice, aged 2 months, with a body weight of $22 \pm 3 G$, were selected and provided by the Laboratory Animal Center of Medical University.

\section{Main drugs and reagents}

The drugs and reagents used in this experiment were selected as follows: Sodium creatine phosphate powder, sodium chloride 0.9\% for injection, lactic acid (LacticAcidLD) test box, creatine kinase (CK) test kit, ATPase test kit, calcium content test kit and homemade three steamed water.

\section{Main instruments}

The experiment required two swimming pools for mice with a water surface area of 0.5 square meters and a water depth of 50 centimeters. The weight of rubber sleeve and iron ring for self-made weight bearing is 2.1-3.0g; A manual glass homogenizer; A model FA2004 electronic balance made by Shanghai Precision Scientific Instrument Co., Ltd. A 2P-200 oscillator; DRAON pipetting gun; Surgical instruments 721; Visible light spectrophotometer; The corresponding wavelength of the enzyme plate instrument; $1000 \mathrm{C}$ constant temperature water bath; Whirlpool mixer and a table centrifuge. ${ }^{5}$

\section{Experimental methods and procedures}

\section{Composition and preparation of main reagents}

1. Homogenating medium.

2. The preparation of ATP reagent was made on site according to the preparation instructions of ATP kit

3. Preparation of creatine kinase (CK) reagent was made on site according to the instructions of the CK kit

4. Preparation of lactic acid (LD) reagent was made on site according to the preparation instructions of the LD kit

5. The preparation of calcium $\mathrm{Ca}^{2}+$ reagent is made on site according to the preparation instructions of calcium $\mathrm{Ca}^{2}+$ kit

\section{Laboratory animal feeding, exercise training program, grouping and weight-bearing exhaustive exercise}

1. Feeding

Fifty pure male Kunming mice, aged 2 months and with a body weight of $22 \pm 3 G$, were selected. Feeding conditions: clean room, temperature control at $25 \pm 2{ }^{\circ} \mathrm{C}$, relative humidity control at $50 \pm 5 \%$. Mice were fed in cages with 13 mice in each cage and 12 mice in each cage. Plastic cage with stainless steel cover and plastic water bottle with stainless steel suction pipe. Under the condition of natural light, they can eat and drink freely. ${ }^{6,7}$

2. Sports training program

- Swimming conditions: the plastic barrel with a diameter of $80 \mathrm{~cm}$ is used as the swimming pool for mice training. The wall of the barrel is smooth, the water depth is $50 \mathrm{~cm}$, more than twice the length of the mouse body, and the water temperature is controlled at $30 \pm 1^{\circ} \mathrm{C}$. To avoid interference between the animals, only five mice were placed in each barrel during swimming training. The glass rod was used to keep the mice from floating on the water and stopping them from swimming. - Exercise scheme: From the 12th day, all mice received swimming training once a day, 5 minutes each time. After swimming, towel dry and blow dry rat fur with a hair dryer. This method of training to the end of the fourth week.

- At the end of the fourth week, the body weight of mice was $40 \pm 3 \mathrm{~g}$. Four groups were randomly divided into group $A(n=12)$ : Non-administration exhaustion group; Group B ( $n=12)$ : exhaustion of administration group; Group C $(n=10)$ : 8 min exercise group without medication; Group D $(n=10)$ : 8min exercise group.- Group B and group D were intraperitoneally injected with phosphocreatine $(1000 \mathrm{mg} / \mathrm{kg}$ body weight) and group $A$ and group C were intraperitoneally injected with normal saline $(1000 \mathrm{mg} / \mathrm{kg}$ body weight). After half an hour, start swimming with weight (6\% weight). Group C and group D were subjected to weight-bearing swimming ( $6 \%$ of body weight) for 8 minutes and sacrificed immediately after removal. Group A and Group B were loaded (6\% of body weight) and swam to exhaustion (exhaustion standard: mice did not return to the surface after submerged for 5 seconds), and the time from the start of exercise to exhaustion was recorded for each mouse, and the head was severed immediately after exhaustion was taken out.

\section{Experimental test index and method}

\section{Exhaustion time}

Use a timer to record the launching time of each mouse and the exhaust time of each mouse. Then calculate the exhaust time of each mouse and divide it into units.

2. Determination of adenosine triphosphate (ATP) in muscle tissue

Creatine kinase catalyzed adenosine triphosphate and creatine to produce phosphocreatine, which was detected by phosphomolybdate colorimetry.

\section{Statistical processing}

SPSS 11.5 statistical software was used for statistical analysis of the results. Measurement data were expressed as mean \pm standard deviation (), the t-test and one-way analysis of variance were used to compare the mean between groups. The test level $a=0.05$, and $P \leq 0.05$ was considered statistically significant. 8,9

\section{RESULTS}

\section{Exercise time of mice}

The exercise time of mice is shown in Table 1 and Figure 1.

As can be seen from Table 1, the mean exhaustive swimming time of untreated mice was $18.1 \pm 5.3$ minutes, while the mean exhaustive swimming time of mice given phosphocreatine was $22.3 \pm 4.7$ minutes.

The mean exhaustion time of swimming mice in the exogenous phosphocreatine group (group B) was significantly longer than that in the non-exogenous group (group A), and the mean exhaustion time was prolonged by $23.20 \%$.

It can be seen intuitively from Figure 1 that the exhaustive exercise time of group $B$ is higher than that of group $A$.

Table 1. Changes of exhaustive exercise time of mice.

\begin{tabular}{c|c|c}
\hline Group & A group & B group \\
\hline The number of cases & 12 & 12 \\
\hline Mean time of exercise (min) & $18.1 \pm 5.3$ & $22.3 \pm 4.7$ \\
\hline $\begin{array}{c}\text { The rate of change of group B } \\
\text { relative to group A was R\% }\end{array}$ & & $23.2 \%$ \\
\hline
\end{tabular}


As can be seen from Table 2 and Figure 2, the mean ATP level of muscle tissue in the 8 min exercise group (group D) was 3.64 \pm 1.17 (umol/ gprot), which was significantly higher than that in the $8 \mathrm{~min}$ exercise group (group C), exhaustion without administration (group A) and exhaustion without administration (group B) $(P<0.01)$. Compared with exhaustion without administration (group A) and exhaustion without administration (group B), 8min exercise group (group C) increased, but $(P>0.05)$ was not statistically significant. ${ }^{10}$

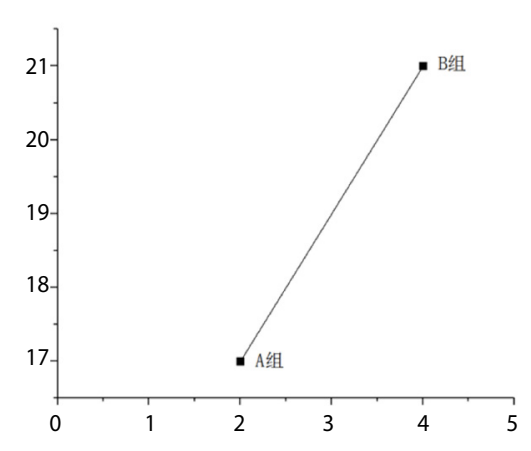

Figure 1. Changes in movement time of mice.

Table 2. Change table of ATP content in muscle tissue of four groups of mice.

\begin{tabular}{c|c|c|c|c}
\hline Group & $\begin{array}{c}\text { The number } \\
\text { of cases }\end{array}$ & $\begin{array}{c}\text { Mean } \pm \text { standard } \\
\text { deviation }\end{array}$ & $\begin{array}{c}\text { The minimum } \\
\text { value }\end{array}$ & The maximum \\
\hline D & 9 & $3.64 \pm 1.17$ & 1.46 & 4.31 \\
\hline B & 9 & $1.41 \pm 1.19$ & 1.62 & 3.19 \\
\hline C & 12 & $2.32 \pm 1.13$ & 1.92 & 4.13 \\
\hline A & 10 & $1.42 \pm 1.58$ & 1.94 & 3.13 \\
\hline Total & 40 & $2.19 \pm 1.51$ & & \\
\hline
\end{tabular}

Note: $F=6.258, P=0.002$.

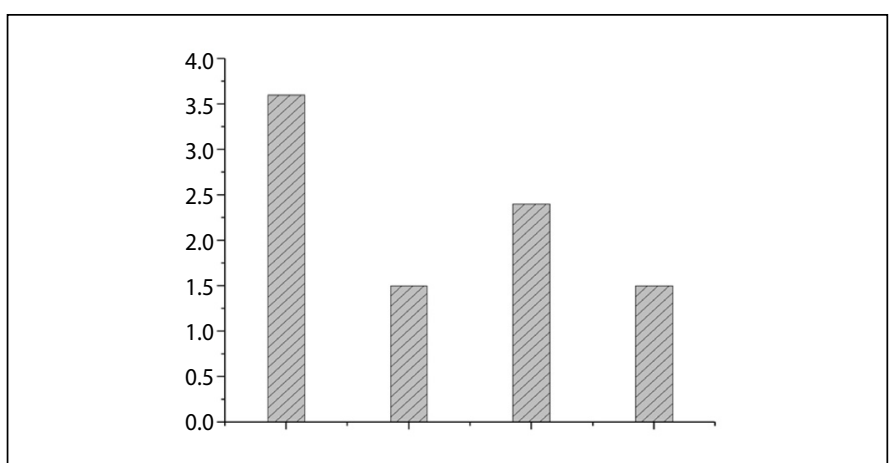

Figure 2. Changes of adenosine triphosphate (ATP) in muscle tissue of four groups of mice.

\section{DISCUSSION}

According to the research materials, phosphocreatine as an energy substance plays a very important role in the improvement of exercise ability. When exercising for a long time with high intensity, the heart work intensifies, myocardial metabolic distress, myocardial cell fluid ATP failure, and phosphocreatine can function under the action of CPK and its isoenzyme, the conversion of ADP into ATP ensures the energy supply of $\mathrm{Na}+-\mathrm{K}+-\mathrm{ATP}$ ion pump and $\mathrm{CA}++$ pump, maintains the transmembrane ion gradient, stabilizes the membrane potential, and reduces the occurrence of arrhythmias. The application of phosphocreatine will significantly improve muscle function, which can make athletes more training and faster muscle recovery after exercise, etc., which will be of great significance to the performance of athletes in the competition. Therefore, phosphocreatine has attracted extensive attention of kinesiologists, and the research on it has gradually deepened. When the body is in metabolic distress after a long period of intense exercise, muscle cells first use phosphocreatine to replenish the amount of ATP, and glycolysis begins to supply energy after a period of time. So, in theory, the more phosphocreatine is stored, the longer the ATP supply will be maintained, and the longer the muscle will be able to withstand a high-intensity workout. Due to temporary ischemia and hypoxia caused by intense exercise, some muscle cells will be damaged by many enzymes, such as phosphocreatine kinase, etc., leaking from muscle cells, and the accumulation of ammonia, adenine and ADP, the nucleotide products decomposed by ATP, in tissues, which will further deepen the damage of cells. And the platelet aggregation caused by these leaks is another important factor in blood vessel blockage and accumulation of metabolites after strenuous exercise. Vascular blockage and waste accumulation after strenuous exercise are the reasons for deepening the deterioration of internal environment and resulting in a series of damage results along the line, such as muscle fiber damage, free radical damage, ischemia reperfusion damage and so on. This is why the use of phosphocreatine can improve capillary blood flow, improve microcirculation, and accelerate the discharge of waste in microcirculation.

\section{CONCLUSION}

In conclusion, the application of phosphocreatine in exercise can improve the maximum aerobic capacity. The improvement of aerobic capacity is to supply the energy needed by the metabolism of myocardium and muscle cells and improve the microcirculation through phosphate creatine, accelerate the discharge of waste in the microcirculation, so as to improve the efficiency of energy metabolism of tissues.

The author declare no potential conflict of interest related to this article

AUTHORS' CONTRIBUTIONS: The author made significant contributions to this manuscript. Lei Ma: writing and performing surgeries; data analysis and performing surgeries; article review and intellectual concept of the article.

\section{REFERENCES}

1. Pisciottani A, Biancolillo L, Ferrara M, Valente D, Sardina F, Monteonofrio L, et al. HIPK2 Phosphorylates the Microtubule-Severing Enzyme Spastin at S268 for Abscission. Cells. 2019;8(7):684. doi: 10.3390/ cells 8070684

2. Veldman W, Liberato MV, Almeida VM, Souza VP, Frutuoso MA, Marana SR, et al. X-ray structure, bioinformatics analysis, and substrate specificity of a 6-phospho- $\beta$-glucosidase glycoside hydrolase 1 enzyme from Bacillus licheniformis. J Chem Inf Model. 2020;60(12):6392-407. doi: 10.1021/acs. jcim.0c00759

3. Yang C. Shenqi Xingnao Granules ameliorates cognitive impairments and Alzheimer's disease-like pathologies in APP/PS1 mouse model. Chinese Herbal Medicines. 2020;12(4):79-87.

4. Masson GR, Williams RL. Structural mechanisms of pten regulation. Cold Spring Harb Perspect Med. 2020;10(3):a036152. doi: 10.1101/cshperspect.a036152

5. Rosenberry TL. Solvent Deuterium oxide isotope effects on the reactions of organophosphorylated acetylcholinesterase. Molecules. 2020;25(19):4412. doi: 10.3390/molecules25194412

6. Lin CH, Lu PH, Yue CT, et al. Chrysophanol Triggers Cell Death via Unfolded Protein Response and
Endoplasmic Reticulum Stress in Oral Cancer FaDu Cells. Current Topics in Nutraceutical Research 2020, 19(1):64-68.

7. Xiong W, Ma H, Zhang Z, Jin M, Wang J, Xu Y, et al. The protective effect of icariin and phosphorylated icariin against LPS-induced intestinal goblet cell dysfunction. Innate Immun. 2020;26(2):97-106. doi: $10.1177 / 1753425919867746$

8. De Schaepdryver M, Goossens J, Jeromin A, Brix B, Van Damme P, Poesen K. Analytical performance of a CE-marked immunoassay to quantify phosphorylated neurofilament heavy chains. Clin Chem Lab Med. 2019;57(8):e199-e202. doi: 10.1515/cclm-2018-1004

9. Qian X, Li X, Shi Z, Xia Y, Cai Q, Xu D, et al. PTEN Suppresses Glycolysis by Dephosphorylating and Inhibiting Autophosphorylated PGK1. Molecular Cell. 2019;76(3):516-527.e7. doi: https://doi. org/10.1016/j.molcel.2019.08.006

10. Mammone T, Chidlow G, Casson RJ, Wood JPM. Improved immunohistochemical detection of phosphorylated mitogen-activated protein kinases in the injured rat optic nerve head. Histochem Cell Biol. 2019;151(5):435-56. doi: 10.1007/s00418-019-01771-x 